\title{
PENGARUH KEDISIPLINAN KERJA TERHADAP SEMANGAT KERJA KARYAWAN (Studi Pada KSP Tunas Artha Mandiri Nganjuk)
}

\author{
Ayu Sulasari \\ Politeknik Negeri Malang \\ Jalan Soekarno Hatta 9 Malang \\ E-mail: ayusulasaripoltek@gmail.com \\ HP. 081334500921
}

\begin{abstract}
Abstrac : The research has been done at KSP Tunas Artha Mandiri in Nganjuk. It examines the influence of disciplines on the employee performance. The objective of this research is, that the employee don't have discipline in the works so that influence the employee performance. The fisrt result from this reseach show that discipline and properous, discipline and punishment, certain on discipline done, discipline support the purpose, participations of the discipline, and the example from leader as key a discipline were influencing the work spirit or performance. The second result show that the dominant factor influence work spirit or performace employee is certained on the discipline done. So we have the conclution that this conditions suitable with actual conditions in KSP Tunas Artha Mandiri-NGANJUK. Although prosperously has a good condition but work spirit or performance employee don't maximal. This is make H2 refused, but if certain on disipline done built up make work spirit or performance employee good more.
\end{abstract}

Keywords: performance or work spirit, discipline, properous, punishment, certain, participations.

Sumber Daya Manusia (SDM) sebagai tenaga kerja pada sebuah organisasi mempunyai peranan yang sangat penting baik secara individu atau kelompok. Manusia sebagai salah satu aset perusahaan merupakan penggerak utama atas jalannya produksi dan jasa, oleh karena itu adanya mutu dan kuantitas sumber daya manusia yang memadai sangat diperlukan bagi suatu perusahaan. Berdasarkan hal tersebut, maka perusahaan harus memperhatikan efektifitas dan efisiensi kerja pada karyawannya, karena karyawan yang 
terdapat dalam perusahaan tersebut mempunyai potensi yang cukup besar yang perlu dimanfaatkan dan dikembangkan semaksimal mungkin.

Disiplin merupakan suatu kekuatan yang seharusnya dimiliki oleh setiap Sumber Daya Manusia, sehingga mereka mampu menyesuaikan diri dengan lingkungan sekitar dan dengan sukarela patuh serta melaksanakan segala keputusan, peraturan-peraturan dan nilainilai yang ada. Disiplin yang melekat pada setiap individu terlihat dari hasil pekerjaan yang dilakukan dan tingkah laku mereka. Disiplin itu sendiri memberikan dampak yaitu:

Dampak positif antara lain: mencegah terhadap terjadinya pelanggaran, prestasi kerja karyawan dapat segera tercapai, menciptakan seseorang atau individu mempunyai rasa tanggung jawab terhadap kepercayaan yang diberikan kepadanya, dan dapat segera tercapainya tujuan bagi organisasi atau perusahaan itu sendiri. Sedangkan dampak negatifnya adalah adanya perasaan yang selalu terbebani pada setiap tindakan yang akan ia lakukan, memungkinkan semakin berkurangnya hubungan yang baik antara pimpinan dan karyawan, dan kesetiaan atau loyalitas karyawan terhadap perusahaan bisa berkurang atau bahkan tidak ada. Apabila karyawan memiliki kesadaran tinggi terhadap disiplin kerja di organisasinya masing-masing, maka semangat kerja akan meningkat dan tujuan perusahaan dapat tercapai. Sebaliknya apabila para karyawan kurang memiliki kesadaran yang tinggi maka semangat kerjanya juga tidak akan baik.

Disiplin kerja karyawan yang menurun merupakan masalah penting dan mendesak untuk segera diselesaikan. Hal ini berkaitan dengan bagaimana kita mengelola dan mendayagunakan sumber daya manusia tersebut serta memberikan umpan balik yang dapat mendorong peningkatan kedisiplinannya, sehingga semangat kerja karyawan meningkat pula. Penyebab dari turunnya semangat kerja dan kegairahan kerja sangat banyak mulai dari yang bersifat umum, misalnya pemberian upah yang dinilai kurang layak, insentif yang tidak terarah, serta fasilitas yang dipandang tidak memadai. Sedangkan sesuatu yang bersifat materi seperti kondisi dan lingkungan kerja yang tidak memberikan ketenangan dan keamanan kerja karyawan, serta timbulnya kejenuhan kerja sebagai akibat dari monotonnya pekerjaan. Pada prisipnya menurunnya semangat kerja disebabkan oleh ketidakpuasan para karyawan. 
Pada organisasi yang memberikan pelayanan jasa, SDM merupakan asset utama pada pelaksanaan kegiatannya. Demikian pula pada usaha jasa koperasi simpan pinjam, dimana kekuatan operasionalnya terletak pada kemampuan sumber daya manusianya dalam mengelola usahanya. Maka kedisiplinan merupakan faktor utama yang layak diperhitungkan. Salah satu contoh usaha pelayanan jasa adalah pada KSP TUNAS ARTHA MANDIRI. Berdasarkan uraian latar belakang diatas, maka bertujuan untuk mengetahui hubungan dan pengaruh Disiplin Kerja terhadap semangat kerja karyawan, dan untuk mengetahui variabelvariabel kedisiplinan kerja yang paling mempengaruhi semangat kerja karyawan.

\section{Tinjauan Pustaka}

Disiplin adalah kesadaran dan kesediaan seseorang mentaati semua peraturan perusahaan dan norma-norma sosial yang berlaku (Hasibuan, 2007). Sedangkan menurut Handoko (2002), "Disiplin adalah kegiatan manajemen untuk menjalankan standar-standar organisasi”. Disiplin merupakan latihan atau pendidikan kesopanan dan kerohanian serta pengembangan tabiat (Martoyo, 2000:125). Berdasarkan pendapat diatas, maka tampak bahwa disiplin kerja merupakan suatu sikap, tingkah laku dan perbuatan dalam mematuhi semua peraturan dan menjalankan standarstandar organisasi yang telah ditetapkan. Disiplin akan mudah terwujud jika timbul dari adanya kesadaran manusia itu sendiri bukan berasal dari motivasi luar.

Disiplin merupakan suatu proses perkembangan yang konstruktif bagi setiap karyawan. Tindakan-tindakan disipliner hanya mempunyai implikasi langsung atas mental karyawan, akan tetapi dapat berpengaruh pada efektifitas dan produktivitas kerja karywan. "Tujuan kedisiplinan adalah untuk memperbaiki kegiatan yang akan datang bukan menghukum kegiatan dimasa lalu" (Handoko,2002:209). Jadi dengan disiplin kerja yang ditanamkan pimpinan kepada karyawan dapat menimbulkan rasa tanggung jawab kepada pekerja sehingga menghasilkan hasil kerja yang baik dan sesuai dengan standar yang telah ditetapkan oleh pihak perusahaan.

Pendisiplinan dapat dibedakan menjadi dua bagian yaitu : Pendisiplinan secara positif dan negatif. Pendisiplinan secara positif adalah dengan cara diberikan nasehat untuk kebaikan dimasa yang akan datang. Sedangkan pendisiplinan negatif meliputi : memberikan peringatan secara lisan, 
memberikan peringatan secara tertulis, didenda, dirumahkan sementara, diturunkan pangkatnya (Husnan, 2008). Dalam hal ini tindakan pendisiplinan digunakan sebagai sarana pencegahan dan bukan semata-mata hanya suatu cara yang dibutuhkan untuk hukuman. Pendapat P.Siagian (2008) menjelaskan pula bahwa terdapat 2 jenis disiplin dalam organisai yaitu yang bersifat prefentif dan yang bersifat korektif. Pendisiplinan preventif adalah tindakan yang mendorong para karyawan untuk taat kepada berbagai ketentuan yang berlaku dan memenuhi standart yang telah ditetapkan. Artinya melalui kejelasan dan penjelasan tentang pola sikap, tindakan dan perilaku yang diinginkan dari setiap anggota organisasi diusahakan pencegahan jangan sampai para karyawan berperilaku negatif.

Pendisiplinan korektif adalah kegiatan yang diambil untuk menangani pelanggaran terhadap aturan-aturan dan mencoba untuk menghindari pelanggaran-pelanggaram lebih lanjut. Kegiatan korektif sering berupa suatu bentuk hukuman dan disebut tindakan pendisiplinan. Jika ada karyawan yang nyata-nyata telah melakukan ketentuan-ketentuan yang berlaku atau gagal memenuhi standar yang telah ditetapkan, maka kepadanya dikenakan sanksi disiplinier. Pengenaan sanksi harus bersifat mendidik, dalam arti agar terjadi perubahan sikap dan perilaku di masa depan dan masa lalu.

Pada prinsipnya kedisiplinan merupakan masalah bagi tiap orang dan merupakan bagian dari manajemen yang sangat penting. Disiplin dapat ditingkatkan dengan jalan meningkatkan kesejahteraan, memberikan peraturan-peraturan yang tegas, baik secara tertulis maupun lisan dan juga dengan mengadakan pengawasan yang diperlukan, dengan demikian diharapkan suatu pekerjaan akan dilaksanakan dengan cara efektif dan efisien sesuai dengan tujuan perusahaan. Cara meningkatkan kedisiplinan tersebut adalah sebagai berikut : keseimbangan kedisiplinan dan kesejahteraan yang cukup, kedisiplinan dan ancaman serta tindakan tegas sebagai pendamping peningkatan kesejahteraan, ketegasan dalam pelaksanaan kedisiplinan perlu dijaga, kedisiplinan perlu dipartisipasikan, teladan pimpinan kunci kedisiplinan (Nitisemito, 2001).

Beberapa pedoman dalam pendisiplinan, antara lain : pendisiplinan hendaknya dilakukan secara pribadi, pendisiplinan haruslah bersifat membangun, pendisiplinan bagi kesalahan yang lama, keadilan dalam pendisiplinan sangat diperlukan, pimpinan tidak 
seharusnya memberikan pendisiplinan pada waktu bawahan sedang absen, setelah pendisiplinan sikap dari pimpinan haruslah wajar kembali. (Husnan, 2008). Sebelum menentukan usaha dalam pelaksanaan peningkatan kedisiplinan perlu diketahui bahwa agar para karyawan dapat melaksanakan tugasnya dengan baik, maka para karyawan tersebut hendaknya diberi kesempatan berkembang mendapat bantuan yang cukup dan adanya dorongan untuk memajukan motivasinya.

Masalah semangat kerja adalah masalah yang sangat penting dan setiap usaha kerja sama kelompok orang dalam mencapai tujuan tertentu dari kelompok tersebut. Pada hakekatnya semangat kerja dan gairah kerja (moral kerja) bersifat subyektif dalam arti tergantung dari perasaan seseorang berhubungan dengan pekerjaannya. Biasanya kita memikirkan semangat dan gairah kerja hanya dari segi negatif saja, yaitu apabila semangat dan gairah kerja tersebut tervisualisasikan saja dalam tindakan nyata, dengan demikian apabila tenaga kerja bergairah dalam bekerja. Maka dapat dikatakan tenaga kerja yang bersangkutan mempunyai derajat moral kerja yang tinggi begitu juga sebaliknya.

Berdasarkan beberapa pendapat di atas, dapat disimpulkan bahwa semangat kerja adalah merupakan iklim atau suasana kerja yang terdapat dalam suatu organisasi. Suasana tersebut adalah suatu sikap mental individu atau kelompok yang terdapat dalam suatu organisasi yang menunjukkan rasa kegairahan dalam melaksanakan pekerjaan mendorong mereka untuk bekerja lebih produktif. Menurut Nitisemito, (2001) Indikasi turunnya semangat kerja adalah : turunnya / rendahnya produktivitas kerja, tingkat turn over (tingkat perpindahan buruh yang tinggi), Tingkat absensi yang tinggi, tingkat kerusakan yang naik/tinggi, kegelisahan dimana-mana, tuntutan yang sering terjadi, dan Pemogokan.

Sedangkan pendapat Zainun dan Kerlinger (2000) menerangkan ada 6 faktor yang mempengaruhi tinggi rendahnya semangat kerja antara lain yaitu : hubungan yang harmonis antara pimpinan dan bawahan, kepuasan petugas terhadap tugas dan pekerjaannya, suasana dan iklim kerja yang bersahabat dengan anggota lain dalam organisasi, rasa kemanfaatan bagi tercapainya tujuan organisasi yang juga merupakan tujuan bersama mereka yang harus diwujudkan secara bersama-sama pula, adanya tingkat kepuasan ekonomi dan kepuasan material lainnya yang memadai sebagai imbalan yang dirasakan adil terhadap jerih payah 
yang telah diberikan kepada organisasi, adanya ketenangan jiwa, jaminan kepastian serta perlindungan terhadap segala sesuatu yang dapat membahayakan diri pribadi dan karier dalam pekerjaannya.

Di samping itu menurut Moekijat, (2002) dijelaskan adanya faktor-faktor yang berpengaruh terhadap semangat kerja dan gairah kerja karyawan adalah : kesempatan dimana pegawai-pegawai dapat memberikan saran-saran seperti bagaimana memperbaiki metode kerja, alat-alat yang ada untuk kerja sama antara pimpinan dan pegawai dalam memecahkan persoalan-persoalan dari badan atau lembaga yang bersangkutan, serta prosedur untuk memperhatikan keluhan. Cara untuk meningkatkan semangar kerja, baik yang bersifat material maupun non material sebagai berikut : Gaji yang cukup, memperhatikan kebutuhan rohani, suasana santai, harga diri perlu diperhatikan, tempatkan para karyawan pada posisi yang tepat, berikan kesempatan untuk maju, perasaan aman tentang masa depan perlu diperhatikan, karyawan perlu mempunyai loyalitas, karyawan perlu diajak berunding, memberikan insentif terarah, dan fasilitas yang menyenangkan. (Nitisemito, 2001)

Secara umum cara yang biasa ditempuh oleh manajemen dalam rangka meningkatkan modal kerja, melalui rancangan sebagai berikut : memberikan kompensasi kepada tenaga kerja dalam posisi yang wajar akan tetapi tidak memaksakan kemampuan perusahaan, menciptakan iklim lingkungan kerja yang menggairahkan bagi semua pihak, memperhatikan kebutuhan yang berhubungan dengan spiritual tenaga kerja, pada saat penyegaran sebagai media pengurangan ketenagakerjaan maupun manajemen, penempatan tenaga pada posisi yang tepat, memperhatikan hari esok tenaga kerja, dan peran serta tenaga kerja untuk mengembangkan aspirasinya. (Siswanto, 2001)

Disiplin kerja yang tinggi akan mengarah kehasil kerja yang lebih baik dan memuaskan, dimana kedisiplinan itu sendiri sangat erat sekali hubungannya dengan semangat kerja. Oleh karena itu apabila seseorang / karyawan sudah memiliki dasar kedisiplinan yang kuat secara tidak langsung, ia juga memiliki semangat kerja yang tinggi dan apabila karyawan kurang memiliki 
kedisiplinan yang kuat otomatis seseorang / karyawan tersebut tidak akan mempunyai semangat kerja yang tinggi. Dari penjelasan tersebut dapat disimpulkan bahwa salah satu ciri manusia sukses adalah manusia yang mampu mengatur dirinya sendiri secara seimbang. Berdasarkan uraian diatas maka dapat disusun model teori sebagai berikut:

Gambar 1:

\section{Model Pengaruh Kedisiplinan Terhadap Semangat Kerja}
Jenis Kedisiplinan
a. Disiplin preventif
1. Ancaman atau tindakan yang tegas.
2. Memasukkan unsur partisipasi bersama.
3. Menanamkan rasa memiliki didalam diri karyawan.
b. Disiplin korektif
1. Penempatan posisi karyawan yang tepat.
2. Pemberian hukuman harus bersifat mendidik.
3. Keteladanan pimpinan.

\section{Gambar 2: \\ Model Hipotesis \\ Pengaruh Kedisiplinan Terhadap Semangat Kerja}

Peningkatan disiplin kerja

1. Kedisiplinan dan kesejahteraan $\left(\mathrm{X}_{1}\right)$

2. Kedisiplinan dan ancaman $\left(\mathrm{X}_{2}\right)$

3. Ketegasan dalam pelaksanaan disiplin $\left(\mathrm{X}_{3}\right)$

4. Kedisiplinan harus menunjang tujuan $\left(\mathrm{X}_{4}\right)$

5. Kedisiplinan yang dipartisipasikan $\left(\mathrm{X}_{5}\right)$

6. Teladan Pimpinan $\left(\mathrm{X}_{6}\right)$

Berdasarkan dari model hipotesis tersebut, maka dapat ditarik hipotesis sebagai berikut : 
H1 :Diduga bahwa kedisiplinan dan kesejahteraan $\left(\mathrm{X}_{1}\right)$, kedisiplinan dan ancaman $\left(\mathrm{X}_{2}\right)$, ketegasan dalam pelaksanaan kedisiplinan $\left(\mathrm{X}_{3}\right)$, kedisiplinan harus menunjang tujuan $\left(\mathrm{X}_{4}\right)$, Kedisiplinan yang dipartisipasikan $\left(\mathrm{X}_{5}\right)$, Teladan pimpinan $\left(\mathrm{X}_{6}\right)$ secara bersama-sama mempunyai hubungan dan pengaruh yang bermakna terhadap semangat kerja (Y).

$\mathrm{H} 2$ :Diduga bahwa kedisiplinan dan kesejahteraan $\left(\mathrm{X}_{1}\right)$ mempunyai pengaruh dominan terhadap semangat kerja (Y) dibanding dengan faktor-faktor lain.

\section{METODE}

Penelitian ini merupakan penelitian explanatory yaitu penelitian yang berusaha menjelaskan hubungan kausal yang terjadi antara variabel - variabel penelitian dan menguji hipotesis yang telah dirumuskan. Lingkup penelitian ini adalah faktor-faktor Pengenbangan Sumber Daya Manusia berupa Kedisiplinan dan kesejahteraan (X1), kedisiplinan dan ancaman (X2), Ketegasan dalam pelaksanaan kedisiplinan (X3), Kedisiplinan harus menunjang tujuan (X4), Kedisiplinan yang dipartisipasikan (X5), dan Teladan pimpinan (X6) yang mempengaruhi Semangat Kerja pada KSP TUNAS ARTHA MANDIRI-NGANJUK.

Teknik pengambilan sampel yang dipakai adalah stratified random sampling, yakni teknik pengambilan sampel dengan membagi populasi dalam strata yang seragam. Selanjutnya dari setiap strata diambil sampel secara acak. Dalam penelitian ini, KSP Tunas Artha Mandiri mempunyai karyawan 150 orang yang terbagi dalam tiga bagian yaitu : Petugas Lapangan, Tenaga administrasi, dan Pengawas Masing-masing bagian diambil dengan prosentase yang sama yaitu sebanyak 20\% x 150 =30.

Untuk mempermudah perhitungan sampel maka dibawah ini akan dilengkapi tabel perhitungan sebagai berikut:

\section{Tabel 1}

Distribusi Sampel Berdasarkan Bagian

\begin{tabular}{|c|c|c|c|c|}
\hline No & Bagian & Jumlah Karyawan & Responden & \\
\hline 1 & Petugas lapangan & 85 orang karyawan & $20 \%$ x 85 & 17 \\
\hline
\end{tabular}




\begin{tabular}{|c|l|c|c|c|}
\hline 2 & Tenaga administrasi & 25 orang karyawan & $20 \%$ x 25 & 5 \\
\hline 3 & Pengawas & 40 orang karyawan & $20 \% \times 40$ & 8 \\
\hline & Jumlah & 150 orang karyawan & & 30 \\
\hline
\end{tabular}

\section{Teknik dan Analisa Data}

Penelitian ini menggunakan analisis korelasi berganda yaitu pengujian yang membuktikan adanya hubungan antara peubah bebas dengan peubah terikat secara bersama-sama.

Dalam uji korelasi berganda adalah sebagai berikut :

$$
\mathrm{R}^{2}=\frac{\text { SSreg }}{\text { SStot }} \text { (Kerlinger, }
$$

Dimana :

SSreg : Sum sqruare regresion

SStot : Sum square total

Untuk signifikan atau tidaknya korelasi tersebut maka digunakan :

$$
\mathrm{F}=\frac{\mathrm{R}^{2} / \mathrm{k}}{\left(1-\mathrm{R}^{2}\right) /(\mathrm{n}-\mathrm{k}-1)} \quad(\text { Sudjana, 2004) }
$$

Dimana :

F : Pendekatan distribusi probabilitas Fischer

$\mathrm{K}$ : Banyaknya Peubah bebas

R : Koefisien Korelasi Berganda

Analisis regresi berganda

Regresi berganda merupakan suatu fungsi yang menunjukkan pengaruh paling dominan dari peubah-peubah bebas terhadap terikat baik secara bersama-sama maupun secara parsial. Alat uji ini menggunakan :

$$
\mathrm{Y}=\mathrm{a}+\mathrm{b}_{1} \mathrm{X}_{1}+\mathrm{b}_{2} \mathrm{X}_{2}+\mathrm{b} 3 \times 3+\mathrm{b} 4 \times 4+\mathrm{b} 5 \times 5+\mathrm{b} 6 \times 6+\varepsilon
$$

Dimana : 


$\begin{array}{ll}\mathrm{Y} & =\text { Semangat Kerja } \\ \mathrm{a} . & =\text { Bilangan konstanta } \\ \mathrm{b} & =\text { koefisien masing masing faktor. } \\ \mathrm{X} 1 & =\text { Kedisiplinan dan kesejahteraan } \\ \mathrm{X} 2 & =\text { kedisiplinan dan ancaman } \\ \mathrm{X} 3 & =\text { Ketegasan dalam pelaksanaan kedisiplinan } \\ \mathrm{X} 4 & =\text { Kedisiplinan harus menunjang tujuan } \\ \mathrm{X} 5 & =\text { Kedisiplinan yang dipartisipasikan } \\ \mathrm{X} 6 & =\text { Teladan pimpinan } \\ \mathrm{C} & \end{array}$

\section{HASIL}

Jumlah tenaga kerja di KSP Tunas Artha Mandiri sebanyak 150 orang, yang terdiri dari :
a. Petugas Lapangan
85 orang
b. Tenaga administasi
25 orang
c. Pengawas
40 orang
Jumlah
150 orang.

Hipotesa 1 menyatakan bahwa peubah kedisiplinan dan kesejahteraan $\left(\mathrm{X}_{1}\right)$, kedisiplinan dan ancaman $\left(\mathrm{X}_{2}\right)$, peubah ketegasan dalam pelaksanaan disiplin $\left(\mathrm{X}_{3}\right)$, peubah kedisiplinan harus menunjang tujuan $\left(\mathrm{X}_{4}\right)$, kedisiplinan yang dipartisikan $\left(\mathrm{X}_{5}\right)$, dan peubah teladan pimpinan $\left(\mathrm{X}_{6}\right)$, secara bersama-sama mempunyai hubungan dan pengaruh yang bermakna terhadap peubah semangat kerja (Y). Untuk menguji Hipotesis I digunakan uji korelasi berganda untuk membuktikan adanya hubungan antara peubah bebas dengan peubah terikat secara bersama-sama hasil pengungujiannya tampak seperti tabel berikut : 


\section{Tabel 2}

\section{Hasil Pengujian Korelasi Berganda}

\begin{tabular}{|c|c|c|c|c|c|}
\hline $\begin{array}{c}\text { Dependent } \\
\text { variabel }\end{array}$ & $\begin{array}{c}\text { Independent } \\
\text { variabel }\end{array}$ & $\mathrm{F}_{\text {hitung }}$ & $\mathrm{F}_{\text {tabel }}$ & $\begin{array}{c}\text { Probabilitas } \\
(\mathrm{sig})\end{array}$ & $\begin{array}{c}\text { Keputusan } \\
\text { Terhadap } \\
\text { Ha }\end{array}$ \\
\hline $\mathrm{Y}$ & $\begin{array}{c}\mathrm{X}_{1}, \mathrm{X}_{2}, \mathrm{X}_{3} \\
\mathrm{X}_{1}, \mathrm{X}_{5}, \mathrm{X}_{6}\end{array}$ & 129,316 & 2,53 & 0,000 & Diterima \\
\hline
\end{tabular}

Sumber : Data Primer, diolah

Berdasarkan perhitungan yang disajikan dalam tabel di atas, maka dapat diartikan bahwa peubah kedisiplinan dan kesejahteraan $\left(\mathrm{X}_{1}\right)$, kedisiplinan dan ancaman $\left(\mathrm{X}_{2}\right)$ peubah ketegasan dalam pelaksanaan disiplin $\left(\mathrm{X}_{3}\right)$, peubah kedisiplinan harus menunjang tujuan $\left(\mathrm{X}_{4}\right)$, peubah kedisiplinan yang dipartisipasikan $\left(\mathrm{X}_{5}\right)$, dan peubah teladan pimpinan $\left(\mathrm{X}_{6}\right)$ secara bersama-sama mempunyai hubungan yang bermakna terhadap peubah semangat kerja $(\mathrm{Y})$. Hal ini dapat dilihat dari tingkat probabilitas (signifikansi) sebesar 0,000 jauh dibawah 0,05. Nilai $F$ hitung sebesar 129,316 dimana niali $F_{\text {hitung }}$ lebih besar dari $\mathrm{F}_{\text {tabel, }}$, maka keputusan $\mathrm{Ha}$ adalah diterima.

R Square didapatkan sebesar 0,971 yang bermakna bahwa dalam persamaan regresi ini peubah kedisiplinan dan kesejahteraan $\left(\mathrm{X}_{1}\right)$, peubah kedisiplinan dan ancaman $\left(\mathrm{X}_{2}\right)$, peubah ketegasan dalam pelaksanaan disiplin $\left(\mathrm{X}_{3}\right)$, peubah kedisiplinan harus menunjang tujuan $\left(\mathrm{X}_{4}\right)$, peubah kedisiplinan yang dipartisipasikan $\left(\mathrm{X}_{5}\right)$, dan teladan pimpinan $\left(\mathrm{X}_{6}\right)$, telah mampu memberikan informasi atau menjelaskan peubah semangat kerja (Y) sebesar 0,971atau $97,1 \%$. Sedangkan sisanya dijelaskan oleh faktor lain diluar peubah bebas yang tidak diteliti dalam penelitian ini sebesar 1-0,971 $=0,027$ atau 2,9\%. Kesimpulan dari perhitungan dan uraian diatas adalah bahwa semua peubah bebas secara bersama-sama mempunyai keeratan hubungan dengan peubah terikat, yang berarti H1 diterima.

Pengujian seluruh hipotesa yang diteliti digunakan untuk membuktikan adanya hubungan antara peubah bebas dan peubah terikat. Untuk menguji hubungan 
dan pengaruh masing-masing peubah bebas terhadap peubah terikat dengan menggunakan regresi berganda yaitu suatu alat analisa untuk mengetahui sejauh mana pengaruh variabel bebas terhadap variabel tergantung (pengaruh), dan korelasi parsial yaitu suatu alat analisa kuat lemahnya hubungan antara variabel. Hasil pengujiannya tampak seperti tabel berikut :

Tabel 3

Hasil Pengujian Regresi Rerganda

\begin{tabular}{|c|c|c|c|c|c|c|}
\hline Depend & $\begin{array}{c}\text { Independen } \\
\mathrm{t}\end{array}$ & $\begin{array}{c}\text { Koefisien } \\
\text { Korelasi }\end{array}$ & Probabilitas & $\mathrm{T}_{\text {hitung }}$ & $\mathrm{T}_{\text {tabel }}$ & $\begin{array}{c}\text { Keputusan } \\
\text { Terhadap } \\
\text { Ha }\end{array}$ \\
\hline \multirow{3}{*}{$\mathrm{Y}$} & $\mathrm{X}_{1}$ & 0,422 & 0,000 & 8,943 & 1.714 & Diterima \\
& $\mathrm{X}_{2}$ & 0,423 & 0,004 & 9,391 & 1.714 & Diterima \\
& $\mathrm{X}_{3}$ & 0,457 & 0,000 & 11,617 & 1.714 & Diterima \\
& $\mathrm{X}_{4}$ & 0,412 & 0,000 & 8,018 & 1.714 & Diterima \\
& $\mathrm{X}_{5}$ & 0,440 & 0,032 & 9,722 & 1.714 & Diterima \\
& $\mathrm{X}_{6}$ & 0,455 & 0,000 & 10,265 & 1.714 & Diterima \\
\hline
\end{tabular}

Sumber : Pengolahan data

Dari hasil perhitungan pada tabel, maka dapat diketahui pengaruh peubah bebas terhadap peubah terikat sebagai berikut :

Kedisiplinan dan kesejahteraan $\left(\mathrm{X}_{1}\right)$. Berdasarkan tabel 3 diatas dapat dikatakan bahwa pengujian peubah kedisiplinan dan kesejahteraan $\left(\mathrm{X}_{1}\right)$ terhadap semangat kerja (Y) menghasilkan koefisien regresi sebesar 0,422 dengan catatan peubah lainnya adalah konstan. Dilihat dari $\mathrm{T}_{\text {hitung }}$ sebesar 8,943 lebih besar dari $\mathrm{T}_{\text {tabel }}$ sebesar 1.714 berarti Ha diterima. Dari pengujian ini dapat disimpulkan bahwa peubah kedisiplinan dan kesejahteraan $\left(\mathrm{X}_{1}\right)$ mempunyai pengaruh terhadap semangat $\operatorname{kerja}(\mathrm{Y})$.

Kedisiplinan dan ancaman $\left(\mathrm{X}_{2}\right)$. Berdasarkan tabel 3 diatas dapat disebutkan bahwa pengujian peubah kedisiplinan dan ancaman $\left(\mathrm{X}_{2}\right)$ terhadap semangat kerja $(\mathrm{Y})$ menghasilkan koefisien regresi sebesar 0,423 dengan catatan peubah lainnya adalah konstan. Dilihat dari $\mathrm{T}_{\text {hitung }}$ sebesar 9,391 lebih besar dari $\mathrm{T}_{\text {Tabel }}$ sebesar 1714 berarti 
Ha diterima. Dari pengujian ini dapat disimpulkan bahwa peubah kedisiplinan dan ancaman $\left(\mathrm{X}_{2}\right)$, mempunyai pengaruh terhadap semangat kerja $(\mathrm{Y})$.

Ketegasan dalam pelaksanaan disiplin $\left(\mathrm{X}_{3}\right)$. Berdasarkan tabel 3 diatas dapat disebutkan bahwa pengujian peubah Ketegasan dalam pelaksanaan disiplin $\left(\mathrm{X}_{3}\right)$ terhadap semangat kerja $(\mathrm{Y})$ menghasilkan koefisien regresi sebesar 0,457 dengan catatan peubah lainnya adalah konstan. Dilihat dari $\mathrm{T}_{\text {hitung }}$ sebesar 11,617 lebih besar dari $\mathrm{T}_{\text {Tabel }}$ sebesar 1.714 berarti Ha diterima. Dari pengujian ini dapat disimpulkan bahwa peubah Ketegasan dalam pelaksanaan disiplin $\left(X_{3}\right)$ mempunyai pengaruh terhadap semangat kerja $(\mathrm{Y})$.

Kedisiplinan harus menunjang tujuan $\left(\mathrm{X}_{4}\right)$. Berdasarkan tabel 3 diatas dapat disebutkan bahwa pengujian peubah Kedisiplinan harus menunjang tujuan $\left(\mathrm{X}_{4}\right)$ terhadap semangat kerja (Y) menghasilkan koefisien regresi sebesar 0,412 dengan catatan peubah lainnya adalah konstan. Dilihat dari $\mathrm{T}_{\text {hitung }}$ sebesar 8,018 lebih besar dari $\mathrm{T}$ Tabel sebesar 1.714 berarti Ha diterima. Dari pengujian ini dapat disimpulkan bahwa peubah Kedisiplinan harus menunjang tujuan $\left(\mathrm{X}_{4}\right)$ mempunyai pengaruh terhadap semangat kerja $(\mathrm{Y})$.

Kedisiplinan yang dipartisipasikan $\left(\mathrm{X}_{5}\right)$. Berdasarkan tabel 3 diatas dapat disebutkan bahwa pengujian peubah Kedisiplinan yang dipartisipasikan $\left(\mathrm{X}_{5}\right)$ terhadap semangat kerja (Y) menghasilkan koefisien regresi sebesar 0,440 dengan catatan peubah lainnya adalah konstan. Dilihat dari $\mathrm{T}_{\text {hitung }}$ sebesar 9,722 lebih besar dari $\mathrm{T}$ Tabel sebesar 1.714 berarti Ha diterima. Dari pengujian ini dapat disimpulkan bahwa peubah Kedisiplinan yang dipartisipasikan $\left(\mathrm{X}_{5}\right)$ mempunyai pengaruh terhadap semangat kerja $(\mathrm{Y})$.

Teladan pimpinan $\left(\mathrm{X}_{6}\right)$. Berdasarkan tabel 3 diatas dapat disebutkan bahwa pengujian peubah Teladan pimpinan $\left(\mathrm{X}_{6}\right)$ terhadap semangat kerja $(\mathrm{Y})$ menghasilkan koefisien regresi sebesar 0,455 dengan catatan peubah lainnya adalah konstan. Dilihat dari $\mathrm{T}_{\text {hitung }}$ sebesar 10,265 lebih besar dari $\mathrm{T}$ Tabel sebesar 1.714 berarti Ha diterima. Dari pengujian ini dapat disimpulkan bahwa peubah Teladan pimpinan $\left(\mathrm{X}_{6}\right)$ mempunyai pengaruh terhadap semangat kerja (Y). 
Hasil pengujian menunjukkan bahwa masing-masing peubah bebas mempunyai pengaruh terhadap peubah terikat. Setelah diketahui pengaruh peubah bebas terhadap peubah terikat diatas, maka dapat dikatakan bahwa peubah ketegasan dalam pelaksanaan disiplin (X3) mempunyai pengaruh yang dominan terhadap semangat kerja (Y). Sehingga H2 ditolak, karena yang berpengaruh dominan bukan X1 tetapi yang mempunyai pengaruh dominan adalah X3. Pada prinsipnya bahwa ketegasan dalam pelaksanaan disiplin (X3) merupakan faktor yang paling dominan dan mempengaruhi semangat kerja, karena secara langsung memaksa karyawan untuk mau melaksanakan segala peraturan yang berlaku.

\section{PEMBAHASAN}

Hasil perhitungan di atas dapat di interpretasikan hubungan dan pengaruh peubah bebas secara bersama-sama terhadap peubah terikat sebagai berikut, bahwa peubah kedisiplinan dan kesejahteraan $\left(\mathrm{X}_{1}\right)$, peubah kedisiplinan dan ancaman $\left(\mathrm{X}_{2}\right)$, peubah ketegasan dalam pelaksanaan disiplin $\left(\mathrm{X}_{3}\right)$ Kedisiplinan harus menunjang tujuan $\left(\mathrm{X}_{4}\right)$, peubah kedisiplinan yang dipartisipasikan $\left(\mathrm{X}_{5}\right)$, dan peubah teladan pimpinan $\left(\mathrm{X}_{6}\right)$ mempunyai hubungan yang bermakna terhadap peubah semangat kerja (Y). hal ini dapat dilihat dari nilai koefisien korelasi sebesar 129,316 dan $F_{\text {tabel }}$ sebesar 2.53 dimana $F_{\text {hitung }}$ lebih besar $F_{\text {tabel }}$. Disamping itu bahwa peubah kedisiplinan dan kesejahteraan menghasilkan koefisien korelasi parsial sebesar 0,422 yang artinya memiliki hubungan positif yang berpengaruh kuat, sedangkan peubah kedisiplinan dan ancaman menghasilkan koefisien korelasi parsial sebesar 0,423 yang artinya memiliki hubungan yang positif yang berpengaruh kuat.

Peubah ketegasan dalam pelaksanaan disiplin menghasilkan koefisien parsial sebesar 0,457 yang artinya memiliki hubungan yang bermakna peubah kedisiplinan harus menunjang tujuan menghasilkan koefisien korelasi parsial sebesar 0,412 yang artinya memiliki hubungan yang bermakna peubah kedisiplinan yang dipartisipasikan, menghasilkan koefisien parsial sebesar 0,440 yang artinya memiliki 
hubungan yang bermakna, serta peubah teladan pimpinan menghasilkan koefisien parsial sebesar 0,455 yang artinya memiliki hubungan yang bermakna.

Pengujian ini dapat disimpulkan bahwa peubah ketegasan dalam pelaksanaan disiplin (X3) mempunyai pengaruh yang paling dominan terhadap semangat kerja. Hal ini sesuai dengan kondisi yang ada di KSP TUNAS ARTHA MANDIRI NGANJUK. Secara teori kedisiplinan dan kesejahteraan paling dominan meningkatkan semangat kerja. Pada kenyataannya di KSP TUNAS ARTHA MANDIRI NGANJUK, ketika disiplin tidak diterapkan secara tegas maka karyawan belum bekerja secara maksimal atau semangat kerja belum maksimal meskipun kesejahteraan sudah diperhatikan. Tetapi ketika disiplin diterapkan secara tegas maka mau tidak mau karyawan harus mematuhi peraturan yang berlaku, dan hal ini akan lebih effektif yang memacu semangat kerja mereka.

\section{KESIMPULAN DAN SARAN}

\section{Kesimpulan}

Koperasi SImpan Pinjam TUNAS ARTHA MANDIRI adalah salah satu unit usaha yang ada pada grup PT. TUNAS ARTHA MANDIRI. Perusahaan ini berkantor pusat di kota Nganjuk yang didirikan oleh H. Moekayat pada tahun 1999. Unit usaha KSP ini memiliki banyak cabang, salah satunya kantor cabangnya ada di kota Malang. Berdasarkan hasil analisis berganda atau Hipotesi II, menunjukkan bahwa Ha ditolak yang berarti bahwa kedisiplinan dan kesejahteraan tidak punya pengaruh dominan terhadap semangat kerja, tetapi yang punya pengaruh paling besar pada semangat kerja adalah ketegasan dalam pelaksanaan disiplin kerja.

\section{Saran}

Hasil penelitian menunjukkan bahwa sebagian besar responden memilih jawaban peubah ketegasan dalam pelaksanaan disiplin sebagai variabel penunjang meningkatnya semangat kerja. Untuk itu perusahaan diharapkan memberikan perhatian lebih terhadap penerapan kedisiplinan secara tegas dengan memberikan 
teguran maupun sanksi terhadap karyawan yang tidak disiplin dalam melaksanakan pekerjaan, hal ini tanpa mengabaikan kelima (5) variabel lain yaitu :Kedisiplinan dan kesejahteraan, Kedisiplinan dan ancaman , kedisiplinan harus menunjang tujuan, kedisiplinan yang dipartisipasikan, dan teladan pimpinan. 


\section{DAFTAR RUKUKAN}

Arikunto, Suharsimi. 2006. Prosedur Penelitian Suatu Pendekatan Praktik. PT. Rineka Cipta, Jakarta.

Hadi Sutrisno. 2004. Analisa Regresi. Yayasan Penerbit Fakultas Psikologi UGM, Yogyakarta.

Handoko, T. Hani, 2002. Manajemen Personalia dan Sumber Daya Manusia. Cetakan Kedua, Penerbit BPFE, Yogyakarta.

Hasibuan, Malayu S.P. 2007. Manajemen Sumber Daya Manusia. Bumi Aksara, Jakarta.

Kerlinger, FN dan Fedhazur E. 2000. Korelasi dan Analisa Regresi Berganda. Terjemahan Buchari Zainun. Nur Cahaya, Yogyakarta.

Moekijat. 2002. Dasar-dasar Motivasi. Pioner Jaya, Bandung.

Martoyo, Susilo. 2000. Manajemen Sumber Daya Manusia. BPFE, Yogyakarta.

Nitisemito, Alex S. 2001. Manajemen Personalia. Ghalia Indonesia, Jakarta.

Ranupandojo, Heidjrachman. Husnan, Suad. 2008. Manajemen Personalia. BPFE, Yogyakarta.

Sudjana. 2004. Metode Penelitian Bisnis. CV. Alfabeta,. Bandung.

Siswanto, Bedjo. 2001. Manajemen Tenaga Kerja. Penerbit Sinar Baru, Bandung.

Siagian, Sondang. 2008. Manajemen Sumber Daya Manusia. Bumi Aksara, Jakarta.

Sugiyono. 2009. Metode Penelitian Bisnis. CV. ALFABETA IKAPI, BANDUNG. 